Butler University

From the SelectedWorks of Shyam Sriram

May 3, 2019

\title{
"Of Acculturative Stress and Integration Distress: The Resettlement Challenges of Bhutanese Refugees in Metro Atlanta"
}

Shyam Sriram, Butler University 
South Asian Diaspora

\section{Of acculturative stress and integration distress: the resettlement challenges of Bhutanese refugees in Metro Atlanta}

\section{Shyam K. Sriram}

To cite this article: Shyam K. Sriram (2019): Of acculturative stress and integration distress: the resettlement challenges of Bhutanese refugees in Metro Atlanta, South Asian Diaspora, DOI: 10.1080/19438192.2019.1609298

To link to this article: https://doi.org/10.1080/19438192.2019.1609298

曲 Published online: 03 May 2019.

Submit your article to this journal $₫$

View Crossmark data $\asymp$ 


\title{
Of acculturative stress and integration distress: the resettlement challenges of Bhutanese refugees in Metro Atlanta
}

\author{
Shyam K. Sriram \\ Department of Political Science, College of Charleston, Charleston, SC, USA
}

\begin{abstract}
Bhutanese refugees represent one of the most recent waves of immigration to the United States. Resettled since 2008, the community finds itself marred by what Berry et al. [1987. "Comparative Studies of Acculturative Stress." International Migration Review 21 (3): 491-511] termed 'acculturative stress', which has resulted in a high level of suicide and fractured communities. This paper contributes to the literature on resettlement through an analysis of the experiences of 32 Bhutanese refugees in Metro Atlanta. The data for this project come from two sets of interviews in 2015 and 2018. The Bhutanese participants exhibited a willingness to engage in the integration process, but this has come with a cost: systematic gaps in the help refugees has created a wave of 'integration distress' that has affected the entire Bhutanese community in Atlanta.
\end{abstract}

\section{ARTICLE HISTORY}

Received 16 September 2018 Accepted 10 February 2019

\section{KEYWORDS}

Bhutan; Bhutanese; refugees; America; Atlanta; suicide; integration; resettlement

\section{Introduction}

Mitra Misha. Dan Maya Gurung. Nirmala Niroula. Menuka Poudel. Bal Khulal. These five names are unlikely to mean much to most people, but they represent five of a suicide epidemic among Bhutanese refugees that have rippled across the United States since 2008 (Preiss 2013; Glionna 2014; Mishra 2014; Hagaman et al. 2016). Bhutanese refugees have completed suicide at twice the rate of the national average, triggering a formal investigation from the Office of Refugee Resettlement and the Centers for Disease Control and Prevention (Hagaman et al. 2016, 820). While suicide is still a major cause of death in the United States, particularly among immigrants (Sher and Vilens 2011), the high incidence of Bhutanese suicides is shocking because this community represents one of the newest groups of refugees to be admitted to the United States, with the initial wave starting in 2008. In response, the CDC produced a report, identifying several key factors that all played a part in the Bhutanese suicides they investigated including lack of English fluency; family problems and separation; and 'difficulty maintaining cultural and religious traditions' (Ao et al. 2012, 1).

Bhutan is an isolated, mountainous, Buddhist kingdom in South Asia, sandwiched between India and China. The country is not a signatory to the International Covenant

CONTACT Shyam K. Sriram sriramsk@cofc.edu

(C) 2019 Informa UK Limited, trading as Taylor \& Francis Group 
on Civil and Political Rights and only established its first constitution in 2008 (Saul 2000; Varennes 2008; Lee 2014). Though internationally recognised for its 'Happiness Index', its ethnic policies over the last three decades have generated a recent refugee crisis (Mørch 2016; Wood 2017).

The persecuted community are the Lhotshampa or 'People of the South' - Bhutanese of Nepali descent. The majority are Hindu, and settled in the southern part of the country in the late nineteenth century due to a labour shortage, later becoming known for their agrarian successes (Hutt 1996; Pattanaik 1998; Giri 2004). In an attempt to create an identity under the banner of driglamnamja (Dzongkha for 'one nation, one people'), the Bhutanese government began a process in the late 1980s of forced integration and assimilation of the Nepali people (Muni 1991). Citizenship, which had been granted so easily before to the Lhotshampa, was now restricted by the Citizenship Act of 1985 to those who had maintained residency.

The government began to expel the Lhotshampa in 1991 creating an international refugee crisis (Giri 2004; Banki 2008; de Varennes 2008; Kumar 2012). The United Nations High Commission on Refugees (UNHCR) resettled Lhotshampa around the world with the United States receiving the most (Benson et al. 2012). 96,023 have been accepted by the United States between 2008 and the end of May 2018; that is over 15\% of all refugees in the last decade (Refugee Processing Center 2018).

The U.S. government has a simplified view of how resettlement should look. In the first step, the refugee arrives in America, and she and her family are taken care of initially by refugee resettlement organizations (RROs) that work with various government entities. Second, the refugee is given, on average, six months of free housing and food stamps, and is expected to quickly find employment, regardless of English fluency. Last, through the simplified expectation of 'making it' and achieving the American dream, the refugee 'assimilates' and becomes American.

This scenario, however, is unrealistic. The refugee resettlement process is never this simple, nor obstacle free, and while many refugees, even within the Bhutanese community, have achieved a considerable degree of vertical mobility and economic success, there is still widespread doubt and fear about the lack of success. If we understand refugee resettlement as a vehicle for the integration of a particular class of immigrants - refugees - then it is remarkable how little attention political scientists have paid to studying resettlement. It is an inherently political process involving many types of institutions and political behaviours.

The Code of Federal Regulations is explicitly clear about resettlement, which is codified in the section on 'Public Welfare'. Title $45, \$ 400.1$ states the primary motivation behind the refugee resettlement programme is 'to achieve economic self-sufficiency as quickly as possible' and 'the provision of employment services and English language training as a priority in accomplishing the purpose of this program' (eCRF 2018). In order to achieve this result, the Office of Refugee Resettlement (ORR), an agency within the Department of Health and Human Services' Administration of Children and Families (ACF) collaborates with various state governments (Martin 2005; Vang 2008). These states subsequently partner with non - governmental organizations (NGOs) and other non-profits to help refugees in different states not only get resettled, but also to get help in adapting to all the changes with living, working and hopefully, thriving, in the United States. ORR allocates federal money to the states, which then goes directly to 
the refugee resettlement organisations, creating a 'public- private partnership with nongovernmental organizations participating in every step of the process' (Vang 2008, 11).

The focus of this article is a study of the Bhutanese community in Metro Atlanta using two sets of interviews with different groups of people who came to the United States as refugees. ${ }^{1}$ The first set of 18 interviews was conducted in January 2015 and focused on the suicide crisis. The second set of 14 interviews took place between December 2017 and January 2018, and the research protocol here was on the initial resettlement experiences after arriving in the United States. Using this innovative methodology generates a strong argument for the role that the resettlement process has in inducing what I have termed 'integration distress' amongst the Bhutanese community. Building on earlier work by Berry et al. (1987), I argue that the 'acculturative stress' experienced by refugees during the process of gaining an American identity coupled with the trauma of displacement and forced migration, sets refugees up for an uneven resettlement experience. 'Integration distress' then becomes a kind of moribund intervening variable that leads to a situation where the Bhutanese often feel helpless.

\section{Methodology}

\section{Case selection: why Georgia?}

Georgia is one of 49 states that currently allows for the resettlement of refugees accepted by the United States government. ${ }^{2}$ The United States has had an official refugee programme in place since World War II, but only with international parity through the Refugee Act of 1980. Between 1975 and 2017, 3,391,323 refugees were accepted into the United States and Georgia has resettled approximately 76, 474 refugees between 1981 and 2015 (Georgia Refugee Health Program 2002, 2015). ${ }^{3}$

Georgia is a bastion of Southern, conservative politics and while it has recently become known as an active bloc of minority legislators, it has, in recent years, become less known for its positive role in Black political identity, and more for its anti-immigrant tone. This manifested itself in the Illegal Immigration Reform and Enforcement Act (HB 87), a 2011 law that gave the police broader profiling powers and made it illegal to knowingly hire undocumented workers (Redmon 2011; Powell 2012). Then, in 2015, Governor Nathan Deal issued an executive order barring Syrian refugees from being resettled in Georgia (Deal 2015).

Georgia was chosen for this analysis primarily due to convenience. I taught at the Clarkston campus of Georgia Perimeter College from 2008 to 2014 and built up strong relationships with various refugee communities. Clarkston, nine miles east of Atlanta, is the resettlement point for all refugees arriving in the state, earning it the nickname the 'Ellis Island of the South' (Long 2017). Georgia is also one of 28 states where the refugee resettlement programme is administered by the individual state often as traditional, bureaucratic departments including the Departments of Human Services, Social Services, Children and Families, and Workforce Development. ${ }^{4}$ In the rest of the country, refugee resettlement is administered as a public-private partnership; by private, religious-based agencies that coordinate directly with the federal government (with apparently no state-level oversight); ${ }^{5}$ or through Wilson-Fish agreements. ${ }^{6}$ Currently, the only state that has no resettlement programme is Wyoming, despite the presence of refugees (Frosch 2014; Zong and Batalova 2017). As a point of understanding, it is helpful to understand that the unit of implementation of resettlement policy is the state, which can decline 
to resettle refugees period; establish independent or unique agencies to handle resettlement; hand over all resettlement and readjustment programming to a private contractor and not even be involved in the process; or monitor and oversee refugee resettlement through traditional line-organisations and state bureaucracies, which can contract with private agencies to handle specific tasks.

\section{The refugees: case selection and recruitment}

My teaching experiences in Clarkston, Georgia from 2008 to 2014 gave me the initial interest in the Bhutanese refugee community through my interactions with Nepali-speaking students. My South Asian background and Hindu name allowed me access to Bhutanese families, which only improved after I started learning Nepali in 2016. To recruit Bhutanese refugees in Georgia I asked three of my former students to introduce me to other community members who came to the United States as refugees and who would submit to an interview. I used a form of respondent-driven sampling to find 'hidden populations' (Heckathorn 2002; Salganik and Heckathorn 2004). This sampling technique was pioneered in sociology and public health to recruit sensitive populations that are often invisible to the mainstream like drug seekers. But this technique is ideal in the context of refugees because they are a sensitive, 'hidden population', and also because a general distrust of government makes their recruitment difficult.

These interviews were conducted in homes, coffee shops, and in more than one occasion, my car (as a quiet, distraction-free zone) in Snellville, Clarkston, Grayson, Stone Mountain, and Lilburn, Georgia. I used the Voice Memos app on my iPhone to record all the interviews, replacing the traditional table mics and/or recorders. I transcribed the interviews later by listening and typing out each interview manually and did not use Dragon or any voice-recognition software.

One final note about the interviews: though the younger participants did not need the help of the translator, none of the interviewees spoke English fluently, and while transcribing the recordings, I noted a lot of their hesitation while speaking. So for sake of brevity and clarity, I modified their language for this paper. For example: 'Here, I feel comfortable ... like I feel comfort ... I am comfortably ... enjoying my religion', became 'Here, I feel comfortable enjoying my religion'.

\section{Results}

Due to the unique nature of the methodology and the two sets of interviews, I have demarcated the results into two chronological sections based on the timing of interviews. In the first, I outline the participant perspectives from the January 2015 interviews when asked about why suicide seemed to have become a dominant problem for the Bhutanese community. In the second, I transition to the qualitative data from the 2017 to 2018 interviews and the refugees' opinions on the resettlement process.

\section{The problem of suicide}

\section{Concern \#1: lack of English fluency}

All of the subjects described the 'language gap' as the most pressing and immediate concern for the community. This, in turn, has created a rift between parents and children. 
According to one 31-year old male (and the translator), 50\% of the parents are educated, and $50 \%$ are not. This leads to a problem where the parents don't speak English

and they don't know anything that is happening to their children. The children take advantage of their parents and they do things outside, and the parents never know. And they do not even know that their children are not in school, or taking drugs outside.

The translator's 23-year old brother, said,

There are a lot of problems. The kids are coming out from high school, and there are so many problems at home. The dad, you know, doesn't speak English and his mom's got the same problem. Job, then bad economy, no job. They [kids] have to work because no one else is paying the rent. There are a lot of them.

An 81-year old participant and venerated figure in the community who was described as 'the living history of Bhutan', also believed that the lack of English fluency was detrimental to the community. When I asked him about his own attempts to pick up the language, he said that he believed he was too old to learn, but that other, older refugees did not want to learn because they felt it would take away from their potential to work and help pay rent.

When asked whose responsibility it was to teach English to the community, a 22-year old male, responded that the lack of English fluency was not the government's problem because the underlying issue was a general lack of family literacy. In his words,

I think what is happening is that our parents, they grow up illiterate, they never have any school, they never know anything of [the] outside world. They [government] is giving facilities [to learn English], but our people, they don't want to go. They don't want to take it.

The translator's sister-in-law, who had become a community leader through her education and success, had a different perspective on English education. She believed the government had provided English classes and ESL tutoring to the refugees when they lived in Clarkston, but those resources had evaporated once community members had moved to the suburbs. She also strongly believed that the impetus for change, particularly on this issue, had to come from within the community. 'I think this is the responsibility for the educated people like me, to connect to the local government', she said. 'I have already started thinking about the need for helping [my] parents to learn English (sic)'. She went on to say that he was working with local leaders to arrange free English classes, particularly for the elderly.

\section{Concern \#2: family divisions}

The lack of English fluency has also contributed partly to major family conflictsin the Bhutanese community. When subjects were asked why some community members were more successful than others, they often pointed to a strong and caring family structure, headed by firm parents focused on discipline. According to the first participant, the translator, his mother is always concerned where her children are, even though all are adults. 'She calls us whenever we go outside', he replied, 'and asks "What are you doing? Where are you? Why aren't you coming back home?" But those people [without education], they do not even know how to dial a phone. That's why their kids are running wild'.

The community elder mentioned previously believed that children were now in control of their parents, and not the other way around. 'If the parents try and control the children', he chimed, 'they will call the government and get them in trouble'. Another community 
leader, a 72-year old male, whom I learned has also been the de facto adjudicator and conflict resolution person in the refugee camps, believed the same. He believed that 'because of the law, they [parents] cannot even scold their children, and because they cannot scold their children, they have to be staying in fear (sic) because their children might fight back and call the authorities'.

A 58-year old widow and matriarch reiterated her son's stance about the role of parents, adding that change had to come from the community to fix, and if that didn't work, police would be the next step, particularly with school truancy. She said, 'All the elders are working and the children are doing whatever ... the parents cannot control their kids'. Another interviewee believed that Bhutanese parents were actually neglecting their kids, but were between a rock and a hard place. Accordingly, 'They have freedom, [but] what can they do? They give the children freedom, they just say nothing. But, after a couple of years, the children go on to the wrong track. They don't know how to raise their kids'.

One surprising issue that came up as either a cause for the lack of family cohesion, or a symptom of it, was a spike in youth marriage, which based on my observations, was particularly hard for this community to stomach since parents were not consulted before the children married. A 24-year old male and community activist who worked with youth, mentioned a 17-year old Bhutanese woman who had already been married four times! As he tersely put it, 'We are free, racing bulls. We have no direction'. He also suggested that the diminished family bonds in the community were also responsible for a rise in domestic violence and divorce. A 21-year old male, believed that marriage had become an issue because Bhutanese youth want to marry people from outside the community. Knowing that the parents will object, they just elope.

We can say whatever we want to our parents. You know if it was in the back country, we would never say we wanted to get married at a young age. I would never say that. But right here? We got a freedom of speech. When you cross 16 or 17 [years of age], even though you are not mentally prepared - you don't even know how to run the house - and you say, 'I want to get married'. What is wrong and what is right - even you don't know, because you've got freedom.

\section{Concern \#3: freedom in America versus Bhutan/ Nepal}

While most of the interviewees were happy to be in the United States - some expressed an interest in moving overseas, particularly to Australia - there was also a feeling that the amount of freedom and liberty in America was almost too much freedom for many of the refugees. According to one participant,

When we first came here, we were a limited group, small group, and we didn't know outside concept of all those outside things. So we didn't go towards it. But right now, these folks, they are very open. They know where to go, what to do.

He used the ideology of prison to compare it to life in the refugee camps. He believed that the Bhutanese had such restrictive lives before coming to the United States that the freedom and lack of authoritarian government made them want to experience everything, good and bad, the country had to offer. His brother said that the Bhutanese were 'uncivilized, uneducated people. Back at home, we had nothing like we have here, so most people think we are in heaven'. According to the translator, 
I think the problem is like in [the] camps, the parents used to rule their children. Here the children are ruling the parents because the parents do not speak [the] language, they do not understand what is going beyond their house walls. The children are ruling their parents, getting married early, doing whatever they want to do.

\section{Concern \#4: school truancy, alcohol, crime, drugs, and gambling}

It is disheartening in many ways that a community that has for the most part been in the United States for less than a decade is already grappling with crime, school truancy, alcoholism, drug abuse, and gambling addiction. A 24-year old woman, recalled that some of her friends 'dropped out of school, stopped coming to school, started using drugs. I know they drink a lot'. Another female participant was first resettled in Texas and moved after marriage. She said that many of the problems in Georgia happened among the Bhutanese in Texas, but that high school dropouts were a particular concern. Another intervieweerecalled a situation where 'these three guys at Montreal Road where I work, they have never been to school this semester. They are in 9th grade'. He went on to discuss the growing issue of refugees robbing others. He said, 'Where I work it's an apartment complex. People know it is robbed by Nepalese. They have taken TVs, computers, bikes, and gold chains and everything. One lady was robbed; $\$ 12,000$ in cash'. He talked openly about his uncle's gambling addiction:

My uncle he used to go gambling, and I every time, I see him go to Food Mart playing the game. We tried to tell him that playing the game, he keep wasting (sic) the money. He has a job, but he doesn't have the income to pay the rent. He used to live in a home, but now he's in an apartment.

One issue minimally discussed was bullying. Not surprising, the 22-year old participant and community activist, believed that bullying was the underlying reason for the high rate of dropouts. Instead of being bullied, a lot of Bhutanese youth started skipping class to hang out with their friends, and that leads to drugs and 'smoking things'. The same thought was echoed by another interview who said that 'because of the freedom, people are doing whatever they want to do. They are drinking, they are gambling. They lost everything they get (sic)'. His 32-year old son had similar feelings: 'When they drink, when they are gambling, they are losing their ability to function; they don't have any money to pay rent'.

\section{Concern \#5: depression and suicide}

My observation was that the high suicide rate among the Bhutanese had greatly affected morale. Most of the interviewees believed that the aforementioned issues - lack of English fluency, parental control, alcohol, drugs, gambling, and 'excessive' freedoms had created a perfect storm that laid the groundwork for depression. One of the youngest interviewees, an 18-year old high school student, said,

There was one guy who worked at the chicken factory, and whatever he earned he just spent it at the gaming show [gaming machine]. And one day, he hanged himself ... and recently, there was one [Bhutanese] guy from South Dakota who wants to help stop people from committing suicide, and it's good for our Nepali people. Probably gaming machine is one of the most problematic things for our community.

My Atlanta-based translator, also a participant in the study, believed the main reason was the gap between parents and children: 'children are not following what the parents are 
saying, and the parents are depressed and they kill themselves. They think their children are gone. That's why'. Another one of my former students, a 20-year old male, mentioned three or four cases of suicide in the community where he believed that alcohol and gaming machines were the obvious culprits.

One of the older participants, a 59-year old illiterate refugee who could not read Nepali or English, was first unable to understand my question about suicide. 'He is unable to understand why this is happening', said the translator, 'because he can't even comprehend suicide. He believes it is because there is a ridge between parents, and the boy and girl, and anyone can participate whenever they want'. Another community elder and a former Hindu priest shared a particularly heartbreaking story about a family where many of its members had converted from Hinduism to Christianity. This, according to him, had left only the father still Hindu and hefelt that this man might commit suicide because his family was destroyed.

In a great summary of the whole issues plaguing the Bhutanese community in Atlanta, the matriarch referenced earlier believed that the community was struggling with five dominant issues: dropouts, drug abuse, alcohol abuse, 'gaming machines' (computerised gambling, not video games), and suicide. Accordingly, she told me,

First of all, there is a type of people that commit suicide because of language barrier. They see everywhere opportunity, but they cannot bring progress on that particular opportunity ... The person cannot speak, cannot communicate. Another reason I think is because of conversion from Hinduism to Christianity. And all this they do because of some selfishness ... You know that Hindu community is divided by caste system. And now when the young people get education, they feel that the caste system is another barrier. Now parents they are still reserved in the caste system, but the educated and the children they want to be free from this, and intermarry outside the caste system ... I hear about this inter-caste marriage and negligence from the parents or the family. This might have given frustration and that caused the suicide.

\section{Findlings: perspectives on resettlement}

This section presents the results and analysis of my second set of 14 interviews with a different group of Bhutanese refugees in Metro Atlanta in the context of my research on the resettlement experiences in Georgia. After refugees arrive in Atlanta, they are met at the airport by a caseworker assigned to help families adjust; each caseworker represents a specific refugee resettlement organization (RRO). The caseworker, it should be noted, has an enormous amount of discretion to make an on-the-spot evaluation or judgment call about the prospective path each refugee can take. This could be due to specific RRO guidelines or the caseworker's street-level decision-making (Lipsky 1980; Allerdice 2011; Darrow 2015; Fee 2018). What is less known is how each caseworker decides who should go to high school; what constitutes an acceptable amount of English knowledge in lieu of attending ESL classes; and the appropriate level or quality of available jobs.

It is this simple flowchart that seems to be emblematic of the myriad of places where policy seems to go wrong and where simple, spur-of-the-moment decisions have enormous consequences for the long-term care of refugees. This does not represent all the potential challenges facing this unique set of clients but does account for several. I have sorted the refugees' experiences across both states into three, main challenges. 


\section{Orientation curricula and exemptions}

All asylum-seekers, whose applications for third-country resettlement are accepted, first go through an orientation in their refugee camps. According to my interviews, the first orientation could be carried out by the International Organization of Migration (IOM) or specific refugee resettlement organizations (RRO) that take on the resettlement from specific countries based on contracts signed with the United States government (for refugees coming to the U.S.). Of the 14 participants in this second phase of the study, 12 remember this camp orientation, but there is a range of memories associated with it. ${ }^{7}$ The general perception is that this first orientation was an introduction to America and included tutorials on flying on an airplane for the first time; using a traffic light; shaking hands; maintaining eye contact; taking the bus; using a Western toilet; not drinking alcohol or chewing tobacco; getting along with neighbours; and other new skills.

Many of my interviewees talked about their wish that the camp orientation should have covered how difficult life was in America, how hard it was to get a job, and the problems they might face. Instead though, the content of the presentation did not back down from saying the refugees would have to work hard, but that life in America was so much better than the camps and that they would be able to own their own homes and cars. My translator believed that part of the orientation in Nepal was that each refugee had to sign a number of forms in Nepali that essentially indicated they had voluntarily attended the orientation and understood the context of life in America (despite most not actually knowing what they were saying). One of these forms, he alleges, was a registration for Selective Service that he says he would not have signed if he had really known what it was about. Another interviewee said that 'the form becomes the orientation'. The agency that resettled him would later tell him that by signing these forms during the initial orientation, he had signed a sort of contract with the RRO that he would abide by the laws of the United States. He told me, 'You signed the form without understanding. You did not really know what you signed and they presume you understood even when you clearly did not'.

The orientation in the United States, the 'second orientation', is arguably the single most important initial experience for any refugee arriving in the United States. Building on the first training in the refugee camp, this second experience for the newly-settled refugee is intended to provide a foundation to encapsulate everything that refugees should expect to deal with wherever they are resettled. For refugees arriving in Georgia, that is life in and around Clarkston, which is part of Metro Atlanta.

So, who attends orientation? This was one of the most surprising findings during my research. Ostensibly, every household member over 18 years of age was supposed to attend, but this rarely happened. Often, only one family member, usually the initial and sole provider, would attend. On top of that, and perhaps one of the contributing reasons to the integration distress I discuss soon, all of my interviewees who did not attend orientation had later problems with integration. This was complicated by two phenomena. First, elder Bhutanese who would have mostbenefited from the orientation, did not have to attend. Since they were already illiterate in Nepali and English, and most had a poor education, this put them at risk for feeling greater isolation.

Second, the RROs often exempted refugees, most likely due to a lack of resources, but at what cost? Several interviewees mentioned saying how harrowing their first few months 
were, but the RRO broadly, and assigned caseworkers more specifically, decided that they [the refugees] did not need to attend orientation. In one case, the caseworker determined during intake that the refugee knew enough English to not need orientation, but the participant claimed how scary it was to navigate government services knowing a bare amount of English, and not be 'eligible' for language help.

\section{What is self-sufficiency, anyway?}

The twin goals of the resettlement programme as employment and English that form a composite integration outcome simply referred to as 'self-sufficiency'. But, over the course of this article, I have explained how self-sufficiency has a tendency to be understood differently by those individuals actually implementing policy, and why that should affect how clients might perceive different expectations from the RRO staff they [refugees] come into contact with in daily interactions. Implementers' attitudes towards self-sufficiency, particularly in terms of a short-term or long-term system of resettlement, should also have certain policy effects.

One of those effects, as experienced by my participants in Georgia, is an overwhelming belief that RRO staff, particularly caseworkers, cared little for the long-term economic success of their clients. This was quite vividly described when refugees discussed their first jobs. After getting those jobs, assistance from caseworkers often vanished overnight, and worse, once the client started making some money, he or she was often ignominiously told that welfare benefits would be cut because they had 'made it'. ${ }^{8}$ According to one Georgia interviewee, he had to take whatever job the agency gave him, and was chastised when he complained:

They emphasized me (sic) to work first. Because in America, they said, no work, then nothing. So they first told [me to] start working, and they put me in a job ... in a chicken plant ... I think I got Social Security after 22 days or one month ... I worked over there like two months and quit. It was hard ... very cold. I saw some people from our community who are vegetarian and had to work in the plants.

Self-sufficiency is not just about getting a job. For Bhutanese refugees under the age of 18, attending high school often became the only option after initial resettlement and a meeting with the RRO and the designated caseworker. Several of my interviewees talked about being forced to attend high school in the United States even though they had already graduated from secondary school in Nepal, Bhutan, or India! Some had even attended a year or two of college but were required to join a local high school. One 25-year old refugee laughed when he described his experience starting ninth grade at Druid Hill High School in Decatur, Georgia ... at the age of 18. He was 22 when he graduated, even though he was already a high school graduate from the refugee camp in Nepal.

In a similar vein, learning English is an important feature of self-sufficiency, but no one I interviewed knew exactly what the criteria were for attending English classes. Again, caseworkers, following their RRO guidelines, implemented unknown guidelines for deciding who should attend ESL classes and for how long. I did not meet a single refugee who took an exit or final test in English to prove or establish a certain level of fluency. Rather, most of the Bhutanese talked about taking classes for anywhere from 30 days to a year, and deciding on their own when they wanted to stop taking classes. I met many Bhutaniharu 
(Bhutanese people) who claimed they had taken English classes instead of working on the advice of their caseworkers and yet, could barely study for the citizenship test, hold a conversation in English, or do more than sign their own names. One refugee in Georgia who had a very low level of English literacy, and was also illiterate in Nepali, said that his caseworker refused to enrol him in ESL classes claiming that it was more important to find work. He mournfully told me during the interview that by never improving his English, he was destined to never work a good job in America.

When I first started this project, my aim was to understand the political integration of refugees. But as I learned more about resettlement, I understood that while civic or political engagement is a vital and often misplaced experience, it is not a priority for policy implementers. In fact, almost all of the implementers I interviewed made it clear that political engagement was not part of the resettlement MoU, and more importantly, that RROs instructed their staff to avoid all political discussion. ${ }^{9}$ Civic integration is a vital part of integration-related programming around the world, even if it is not considered a priority in the U.S.

Of the 14 refugees I interviewed between December 2017 and March 2018, about half (7) claimed an interest in politics, but one that was not fostered by the RROs. Besides reminders to apply for Green Cards and take citizenship tests, the Bhutanese were usually not asked to participate in politics or political activities. A couple of refugees in Georgia also shared their political experiences with me. One knew nothing of American politics, until two people came to her apartment and asked if she knew about Ted Terry, the Mayor of Clarkston. One of the people spoke Nepali, and he explained to her that Terry, the incumbent, was very supportive of refugees and he was good for the Bhutanese community. With no other sources of political knowledge or mobilisation, this woman registered to vote on the spot, and subsequently voted in her first election. That experience had stayed with her and during our interview, she gleefully told me that she had continued to vote in other elections. Lastly, a former student of mine who had become the family's patriarch before the age of 30, was not critical of the resettlement agency's lack of interest in mobilising him but was critical of the larger Bhutanese community. He was frustrated at the lack of education and the apathy about the basics of the political process, so he taught his family about politics and then took his mother and grandparents to vote because it was important to him that the family participated.

\section{Integration distress}

While many of these feelings could also be the result of the trauma of the refugee experience including living in camps, displacement, torture, imprisonment, and family separation, I argue that a mottled and pervious resettlement experience makes refugees feel like they have nowhere else to go (literally and figuratively). RRO directors, managers, caseworkers, and volunteers may express concerns about previous trauma, but trauma is not in kept in mind as a consequence of the actual process. To put it succinctly, the refugee resettlement process creates new and additional traumas.

I have coined the expression 'integration distress' to account for the trauma of resettlement experienced by Bhutanese refugees in my study, but likely become a part of life for other refugee communities in the United States as well. Integration distress, as I understand it, is a general malaise and loss of confidence in not only the U.S., but also in the 
resettlement process, individual RROs and their staff. Many of my interviewees felt frustration, sadness, depression, vulnerability, and lack of efficacy about their futures in this country.

Integration distress was felt by most of the participants in my study but manifested itself in different ways. Older interviewees believed there was never an opportunity to learn English because their caseworkers insisted they first find jobs, even terrible ones, and it was more important to work than learn a new language. These interviewees seemed forlorn discussing the topic of English during our interviewees and expressed the wish to go back in time and decide on learning English first. Since they could not, they were resigned to steady jobs that were not glamorous, but at least provided a steady source of income. Some of the older interviewees also talked about never getting a chance to attend the secondary, local orientations because the family caseworkers deciding the older family members could not work and were eligible for SSI that would preclude them from working.

Another form of integration distress was the fleeting relationships with caseworkers, many of whom were not fulltime RRO employees, but actually volunteers. Previous work has documented the frustrations felt by refugee resettlement workers who cannot control the number of clients they receive, so services provided vary greatly (Darrow 2015). The transient nature of caseworkers led many refugees to be confused about whom to talk to because they were so dependent on outside assistance. Very few of the agencies had designated Nepali speakers, and most of the caseworkers were not of Nepali or Bhutanese descent and could not speak the language of the clients. A former refugee in Snellville, Georgia, whose elderly parents were both confined to the house and had never worked, mentioned how confusing it was to come to the U.S. during the winter, not know anything, but have a wonderful caseworker who picked them up from the airport and took them everywhere. And then he was gone, quitting after just two months. Incidents like this often created a divide between the refugee family and their agency.

\section{Discussion}

The tussle between America and its immigrant past and identity have resulted in a contentious history, one that is forced to confront a series of inconvenient truths. Mortland (2001) highlights one in particular - the confusion over what exactly makes one American. This unspoken 'model' of economic dependence, learning English, and adopting certain political opinions was understood by those already in America and silently agreed upon by successive waves, became the framework with which past immigrants-turned-Americans have judged future arrivals. Continued demands for immigrants precipitate a continued demand for integration (Alba and Foner 2015).

This country's inability to reach any kind of consensus on immigration policy is also due to a binary conflict of another kind: 'diversity' versus homogeneity' (Higham [1975] 1993, 4). The American public and elites are constantly torn about the need to present the United States as welcoming, but also insistent that a certain way of life must be maintained at all costs, even if keeping up appearances means not welcoming everyone. For Higham ([1975] 1993), 'One legend puts the immigrant, and all he represents, at the center of American experience. Another relegates him to the periphery' (4). 
My thirty-two detailed, individual and group interviews with Bhutanese refugees in 2015 and 2017/2018 lend strong support that there is a pervasive and persistent 'implementation gap' that exists between the statutory integration goals of the federal and state governments and the actual experiences of refugees. Refugees pointed to hurried, poorly- implemented resettlement experiences that did little to integrate them socially into American life. Instead, some refugees were forced to attend school, even if they had already finished high school or attended college in Nepal, Bhutan, or India; and others to seek employment at subpar jobs. Worse, my findings in both states show a pattern of initial enthusiasm from an array of RROs that peter out quickly and do nothing to support the long-term success of refugees after an initial 90- to 180-day welcome period. Compounded by initial and overlooked experiences with trauma, the refugees I interviewed in both states were often faced with what I have called 'integration distress', or a kind of resettlement-related PTSD.

I conclude that this research points to not only an implementation gap, but a failure of implementation of statutory integration outcomes in both states. All states are not the same, and neither are resettlement agencies. If an agency emphasises political integration - and makes it a part of their mission and programming - then this emphasis is passed on to their clients (refugees). This is a remarkable finding because political integration is not emphasised by the federal government and is often not even part of the discussion of selfsufficiency. But if implementers at the state or county levels, or with a refugee resettlement organization (RRO), decides that it is an integration agenda to be pursued, then it is. The ramifications of this kind of unilateral decision-making and implementation are huge. While the Office of Refugee Resettlement may track integration patterns across the states, primarily through oversight, refugees may receive remarkably different levels of care simply depending on the state where they are resettled and perhaps, the county or city where the regional RRO is based. The question is not whether an implementation gap exists (because it does). The question is whether it is fair for a refugee, newly arrived in the United States, to receive support for certain integration outcomes and not others. At its most basic level, this appears to be a failure of federalism, and a violation of equal protection.

\section{Notes}

1. Approved by the Office of Research (Application for the Use of Human Subjects) at the University of California at Santa Barbara (Protocol Nos. 13-14-0829 and 45-17-1051).

2. Wyoming has no resettlement programme.

3. This number only includes the years 1981 to 2001, and 2004 to 2015 .

4. https://www.acf.hhs.gov/orr/state-programs-annual-overview.

5. Catholic Charities operates programmes in Alabama, Alaska, Kentucky, Louisiana, Tennessee, West Virginia, Maine, Mississippi, and Nevada; International Rescue Committee in Montana; Lutheran Social Services in North and South Dakota; U.S. Committee for Refugees and Immigrants in Vermont; and Jewish Family Services in Delaware and Illinois.

6. These agreements arose out of the 1984 Wilson-Fish Amendment to the Immigration and Nationality Act. Under this agreement, participating states do not provide cash assistance to refugees through Temporary Assistance to Needy Families (TANF). Refugees are given other forms of government support in a manner that fosters self- sufficiency, reduces the likelihood of welfare dependency, and fosters greater coordination among resettlement agencies and service providers in a community' (ORR 2015, 3). 
7. Three were too young at the time and were not required to attend. Their elder siblings or parents often did.

8. It is important to note here that $\$ 400.77$ of the federal code does allow for refugee cash assistance to be cut if a client terminates employment within 30 days of getting hired, and does not clarify about quality of life, quality of employment, potential hazards, or any other reason why the refugee may have left employment.

9. The interviews with policy implementers in Georgia [and California] are part of a paper, also being prepared for publication.

\section{Acknowledgements}

Previous versions of this article were presented at the 2018 Politics of Race, Immigration, and Ethnicity Consortium (PRIEC) at the University of Houston and the 2018 Critical Refugee Studies Conference at the University of California at Los Angeles. The author would like to thank the anonymous reviewer, conference participants, and Khem Regmi, मेरोराम्रोसाथी|.

\section{Disclosure statement}

No potential conflict of interest was reported by the author.

\section{Funding}

The second set of interviews were made possible due to a 2018 Critical Refugee Studies Grant from the Critical Refugee Studies Collective (Funded by the University of California Office of the President Multicampus Research Programs and Initiatives).

\section{Notes on contributor}

Shyam Krishnan Sriram is a Visiting Assistant Professor at the College of Charleston, Department of Political Science, 114 Wentworth Street, Charleston, SC 29401, USA.

\section{ORCID}

Shyam K. Sriram (1) http://orcid.org/0000-0003-2164-3550

\section{References}

Alba, Richard, and Nancy Foner. 2015. Strangers No More: Immigration and the Challenges of Integration in North America and Western Europe. Princeton, NJ: Princeton University Press.

Allerdice, Hannah. 2011. "The Effects of Settlement Policy on Refugee Political Activism: Sudanese Refugees in Australia and the U.S.” PhD diss., Syracuse University.

Ao, Trong, Eboni Taylor, Emily Lankau, Teresa I. Sivilli, Curtis Blanton, Sharmila Shetty, Barbara Lopes-Cardozo, Jennifer Cochran, Heidi Ellis, and Paul Geltman. 2012. "An Investigation into Suicides among Bhutanese Refugees in the U.S., 2009-2012." Centers for Disease Control and Prevention and Massachusetts Department of Public Health, October 18.

Banki, Susan. 2008. "Resettlement of Bhutanese from Nepal: The Durable Solution Discourse." In Protracted Displacement in Asia: No Place to Call Home, edited by Howard Adelman, 29-55. England: Ashgate.

Benson, G. Odessa, Fei Sun, David R. Hodge, and David K. Androff. 2012. "Religious Coping and Acculturation Stress among Hindu Bhutanese: A Study of Newly-resettled Refugees in the United States." International Social Work 55 (4): 538-553. 
Berry, John W., Uichol Kim, Thomas Minde, and Doris Mok. 1987. "Comparative Studies of Acculturative Stress.” International Migration Review 21 (3): 491-511.

Darrow, Jessica H. 2015. "Getting Refugees to Work: A Street-level Perspective of Refugee Resettlement Policy.” Refugee Study Quarterly 34 (2): 78-106.

Deal, Nathan. 2015. "Executive Order." The State of Georgia, November 16. https://gov.georgia.gov/ sites/gov.georgia.gov/files/related_files/document/11.16.15.02.pdf.

de Varennes, Fernand. 2008. "Constitutionalizing Discrimination in Bhutan: The Emasculation of Human Rights in the Land of the Dragon." Asia-Pacific Journal on Human Rights and the Law 2: $47-76$.

eCFR (Electronic Code of Federal Regulations). 2018. "Refugee Resettlement Program.” (Title 45, Subtitle B, Chapter IV, Part 400). https://www.ecfr.gov/cgi-bin/textidx?SID=bdd32ffe407b7 155ffcdd0a4f3e1b055\&mc=true\&node=pt45.2.400\&rgn=div5.

Fee, Molly. 2018. "Paper Integration: The Structural Constraints and Consequences of the U.S. Refugee Resettlement Program.” Migration Studies. https:/academic.oup.com/migration/ advance-article/doi/10.1093/migration/mny016/5048699?guestAccessKey=2fd796b6-19c943da-a5b0-fc8ead65517d. Advance Publication.

Frosch, Dan. 2014. "Wyoming Considers Steps to Assist its New Refugees." The Wall Street Journal, September 21. https://www.wsj.com/articles/wyoming-considers-steps-to-assist-refugees-14113 42207.

Georgia Refugee Health Program. 2002. "Refugee Arrivals 1981-2001.” https://garefugees.files. wordpress.com/2011/03/refugee-arrivals-1981-20011.xls.

Georgia Refugee Health Program. 2015. “Annual Refugee Arrivals by Origin for FY 2004-2015.” https:// garefugees.files.wordpress.com/2011/03/annual-refugee-arrivals-by-county-for-ffy2004-20151.xls.

Giri, B. R. 2004. "Bhutan: Ethnic Policies in the Dragon Kingdom." Asian Affairs 35 (3): 353-364.

Glionna, John M. 2014. "Immigrant Keeps Suicide Watch Over Fellow Refugees from Bhutan.” LA Times, October 14. Accessed March 18, 2015. http://www.latimes.com/nation/la-na-c1bhutanese-suicides-20141008-story.html\#page $=1$.

Hagaman, Ashley K., Teresa I. Sivilli, Trong Ao, Curtis Blanton, Heidi Ellis, Barbara Lopes Cardozo, and Sharmila Shetty. 2016. "An Investigation into Suicides among Bhutanese Refugees Resettled in the United States between 2008 and 2011." Journal of Immigrant and Minority Health 18: 819-827.

Heckathorn, Douglas D. 2002. "Respondent-driven Sampling: A New Approach to the Study of Hidden Populations.” Social Problems 44 (2): 174-199.

Higham, John. [1975] 1993. Send These to Me: Immigrants in Urban America. Baltimore: The Johns Hopkins University Press.

Hutt, Michael. 1996. "Ethnic Nationalism, Refugees, and Bhutan." Journal of Refugee Studies 9 (4): 397-420.

Kumar, Sanjeev. 2012. "Snapshot: The Sangh Parivar and Bhutanese Refugees: Constructing a Hindu Diaspora in the United States." In Public Hinduisms, edited by John Zavos, Pralay Kanungo, Deepa S. Reddy, Maya Warrier, and Raymond Brady Williams, 392-397. New Delhi: Sage.

Lee, Darius. 2014. "Here There Be Dragons! Buddhist Constitutionalism in the Hidden Land of Bhutan." Australian Journal of Asian Law 15 (1): 1-19.

Lipsky, Michael. 1980. Street-Level Bureaucracy: Dilemmas of the Individual in Public Services. New York: Russell Sage Foundation.

Long, Katy. 2017. “This Small Town in America's Deep South Welcomes 1,500 Refugees a year.” The Guardian, May 24. https:/www.theguardian.com/us-news/2017/may/24/clarkstongeorgia-refugee-resettlement-program? $\mathrm{CMP}=\mathrm{fb} \_$gu.

Martin, David A. 2005. The United States Refugee Admissions Program: Reforms for a New Era of Refugee Resettlement. Washington, DC: Migration Policy Institute.

Mishra, T. P. 2014. “American Dream Becomes Nightmare for Bhutanese Refugees.” India Real Time (Wall Street Journal Blog), January 7. Accessed October 26, 2014. http://blogs.wsj.com/ indiarealtime/2014/01/07/american-dream-becomes-nightmare-for-bhutanese-refugees/.

Mørch, Maxmillian. 2016. "Bhutan's Dark Secret: The Lhotshampa Expulsion.” The Diplomat, September 21. https://thediplomat.com/2016/09/bhutans-dark-secret-the-lhotshampa-expulsion/. 
Mortland, Carol A. 2001. "Introduction.” In Manifest Destinies: Americanizing Immigrants and Internationalizing Americans, edited by David W. Haines and Carol A. Mortland, 1-10. Westport, CT: Praeger.

Muni, S. D. 1991. "Bhutan in the Throes of Ethnic Conflict." India International Center Quarterly 18 (1): 145-154.

Office of Refugee Resettlement. 2015. "Family Self-sufficiency Plan Example - After First Six Months." Administration for Children \& Families, United States Department of Health and Human Services. Accessed March 20, 2015. http://www.acf.hhs.gov/programs/orr/resource/ family-self-sufficiency-plan-example-after-first-six-months.

Pattanaik, Smruti S. 1998. "Ethnic Identity, Conflict, and Nation Building in Bhutan." Strategic Analysis 22 (4): 635-654.

Powell, Benjamin. 2012. “The Law of Unintended Consequences: Georgia's Immigration Law Backfires.” Forbes (Capital Flows, Opinion), May 17. https:/www.forbes.com/sites/realspin/ 2012/05/17/the-law-of-unintended-consequences-georgias-immigration-law-backfires/ \#2da2dd03492a.

Preiss, Danielle. 2013. "Bhutanese Refugees are Killing Themselves at an Astonishing Rate." The Atlantic, April 13. Accessed March 18, 2015. http://www.theatlantic.com/international/ archive/2013/04/bhutanese-refugees-are-killing-themselves-at-an-astonishing-rate/274959/.

Redmon, Jeremy. 2011. "Georgia Lawmakers Pass Illegal Immigration Crackdown.” The Atlanta Journal-Constitution, April 15. https://www.ajc.com/news/local/georgia-lawmakers-pass-illegalimmigration-crackdown/dvEcDeIuAOvpGvoHzCVodN/.

Refugee Processing Center. 2018. “Summary of Refugee Admissions as of May 31, 2018.” United States Department of State (Bureau of Population, Refugees, and Migration). http://www. wrapsnet.org/admissions-and-arrivals/

Salganik, Matthew J., and Douglas D. Heckathorn. 2004. "Sampling and Estimation in Hidden Populations Using Respondent-driven Sampling." Sociological Methodology 34 (1): 193-240.

Saul, Ben. 2000. "Cultural Nationalism, Self-determination, and Human Rights in Bhutan." International Journal of Refugee Law 12 (3): 321-353.

Sher, Leo, and Alexander Vilens. 2011. Immigration and Mental Health: Stress, Psychiatric Disorders, and Suicidal Behavior among Immigrants and Refugees. Hauppage, NY: Nova Science.

Vang, Chia Youyee. 2008. Hmong in Minnesota. Manitoba: Minnesota Historical Society Press.

Varennes, Fernand de. 2008. "Constitutionalizing Discrimination in Bhutan: The Emasculation of Human Rights in the Land of the Dragon." Asia-Pacific Journal on Human Rights and the Law 2: 47-76.

Wood, Patrick. 2017. "What Happens When a Country Strives for Happiness - At Any Cost?" $A B C$ News, June 22. http://www.abc.net.au/news/2017-06-23/bhutan-strives-for-happinessbut-at-what-cost/8633424.

Zong, Jie, and Jeanne Batalova. 2017. "Refugees and Asylees in the United States." Migration Policy Institute, June 7. https://www.migrationpolicy.org/article/refugees-and-asylees-unitedstates. 